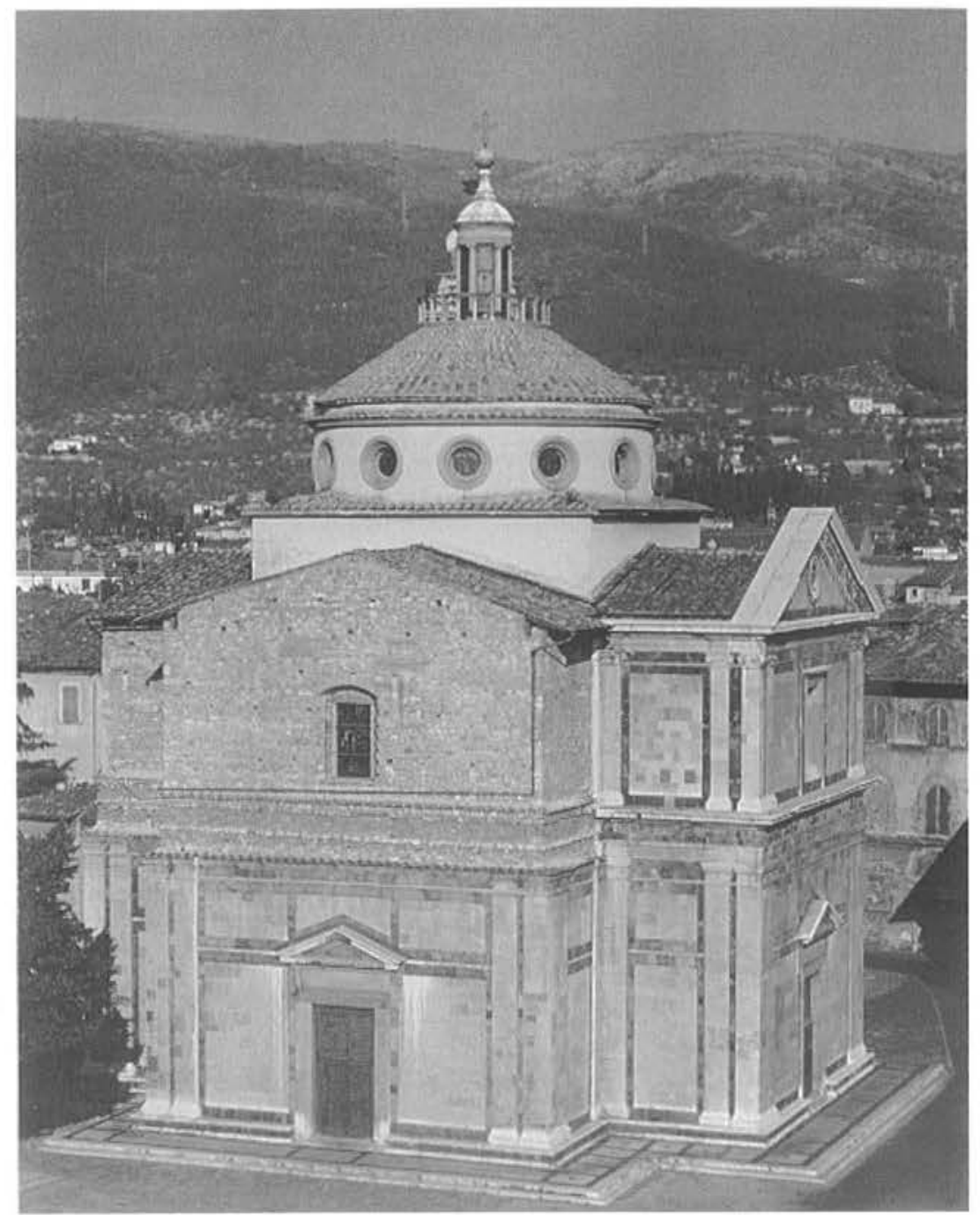

GIULIANO DA SANGALLO (?).

S. Maria delle Carceri, Prato. 1485-95.

\section{FACING FRONTING}

Gordana Kostich-Lefebvre 
The face opens the primordial discourse whose first word is obligation, which no "interiority" permits avoiding.

-Lévinas, "Ethics and the Face"1
This exercise is merely the beginning of an etymological study on the façade. It is less a search for an historical perspective of the building surface than a routine task of monitoring the "good old" foundation of architectural terms and meanings. It examines the ancient terminology for its own contemporary cracks, as much as it watches for the appearance of newer ones, in order to ensure that not too much falls into them. Scrutinising the façade and dusting it off will inevitably upset our ordinary architectural terminology, but I hope that it will also refresh memories. Nor will some relearning of "other" dimensions communicated through our "banal" façade be excluded. Aspects of frontality are the main issue.

The English word façade was imported from the French in the sixteenth century. The French, in turn, devolved from the Italian facciata, and the Latin facies, appearance. Another cognate is faccia, "face" in modern Italian (facia in Vulgar Latin). They all stem from facereto make, render, realise, execute. Is the façade an ontological extension of making?

The term that Vitruvius consistently and predominantly used for the front of a building is "simply" frons, frontis, meaning literally forehead ${ }^{2}$ (Gr. metopon), brow- the prominent part of the face (Gr. prosopon). ${ }^{3}$ Transferred to a building, this became frons aedem, or the famous frons scenae; thus in fronte et postico templi, "in front and back of the temple" is said, not in antico et postico. In the genitive, frontis, ${ }^{4}$ frons also designated a forepart of a book, hence the frontispiece. ${ }^{5}$ In medieval vocabulary frontispicium Ecclesiae was, of course, the principal façade. It is the straightforwardness (frontality) of frons that establishes a facing situation and enables a direct, dignified (appropriateness emphasised), honest (essential) encounter, thus imposing a certain (moral) authority. The "front" is a stature. ${ }^{6}$ Everything relating to it is referential, even in modern languages. The "front" is unequivocally situated both on the artefact to which it belongs as the superior side, and also in direct relation with another, necessary, engaged party, be it a river, park, piazza or an admirer. A constant in this coupling is a variable traversable distance between "participants." In order to approach the "front," a façade has to be qualified as the main façade.

The proper Latin verb for face, to stand opposite, is (a)spectare; aspectus, view, and conspectus, full view, are the "correct" nouns. It is the viewing, looking at, observing as a spectator, just as in "real" theatrical performances, that turns the observed into a spectacle. In addition, the buildings, altars and images of gods "actively"7 look at - they spectant; and in turn, they are looked at and receive regard. Vitruvius revealed a lot about these "exchanges" in Book Four, chapter five- "How the Temple Should Face."

For a moment, let us move around Vitruvius, and consult his contemporary Varro, the linguist. In his own pursuit of retrieving the meanings of "obscured words" in the first century A.D., Varro provided an explanation that is still useful for the meaning and relationship between
1. Emmanuel Lévinas, Totality and Infinity: An essay on exteriority (Pittsburgh: Duquesne University Press, 1969), 201.

2. When dealing with the building/body analogy, and discussing proportioning the face (os capitis and ipsius oris) in iii.1.2, Vitruvius referred to the human forehead, frons.

3. Vitruvius used other common words for appearance, like species (the particular "looks" which distinguish a class of objects/creatures sharing similar appearances); where we could, with regard to a building, possibly use façade (but not "elevation," as it stands in the infelicitous Loeb translation), although classes, kinds, and species better fit in some cases (below, De Architectura, iii.3.1). "Recognisable appearance" is adequate and would preserve a little of spectare in species. Vitruvius, De Architectura, for example in iii.3: species autem aedium sunt quinque ("there are five classes [according to their appearance] of buildings"); or in i.1.4: operis speciem deformare valeat ("speaking about the drafting skills of architects needed to present the appearance (looks) of the works which they want to create"). Architectural drawing devices, which fall into species, are obviously undifferentiated; they are anything drawn to clarify an architect's intentions. In the preface to Book Five, species are the sides of a cube.

4. The nominative homonym frons, frondis $f$. (leaf, foliage) points to the possible visual interplay between faces and leafy vegetation as a result of semantic closeness. This is evidenced in the conjuring up of numerous facial and vegetal representations.

5. Frons + species $=$ first and foremost frontal appearance.

6. To which status relates both etymologically and logically; both stemming from the Sanskrit sta, to stand up. 
facere, "to make," and facies, "external appearance," "face," although he wrongly (customarily) derived the verb from the noun instead of vice versa.

$\mathrm{He}$ is said to make (facere) a thing who puts external appearance (facies) on the thing which he makes (facit). As the image maker (fictor) when he says "I shape" (fingo) puts a shape (figura) on the object, and when he says "I form" (formo) puts form (forma) to it, so when he says "I

7. The verb is used in the active sense. The building faces and/or looks at itself. It is not being looked at. The spectators, on the other hand, look at it on their own.

8. Varro, De Lingua Latina, trans. Roland G. Kent (Loeb Classical Library, 1967), vi.viii.78. Varro developed a theoretical stance that presents facere as closest to crafting in vi.42, where he introduced the concept of an action (actionum) as a tripartite process consisting of firstly motion of the mind (agitatus mentis); secondly, consideration (cogitare), which corresponds to the design or planning of that which shall later be done or said (dicere or facere); and, finally, that which is done or said (facere or dicere).

9. Varro's further careful distinction of facere (to make) from similar, interfering verbs like agere (to act, do) and gerere (to carry, carry on) opens with "for a person can facere something and not agere it" (vi.viii.77); and develops into defining facere in terms of the level of subject's participation in action. He also notes the popular contemporary corruption of the purity of these verbal uses. "But because general practice has used these words indiscriminately rather than with care, we use them in transferred meanings; for he who says something (dicit) we say make words (facere verba), and he who acts something (agit) we say is not inficiens, 'failing to do' something (inficientem)." (vi.viii.78)

10. Varro, De Lingua Latina, vi.viii.78.

11. Lévinas, Totality and Infinity, 78.

12. What is known as the "principle of frontality" in art is rather common to buildings, especially those of importance: temples, palaces, government buildings, and buildings of foreign stat(e)-ure or representation. The supreme examples of frontal representation in art are the Byzantine devotional icons. In Christian art generally "the degree of frontality sometimes seems to correspond to the sanctity of the person depicted, Christ, the Virgin and angels being portrayed full face, the apostles three-quarters, while Judas and other evil-doers might even be in profile." James Hall, The History of Ideas and Images in Italian Art (New York: Harper \& Row, 1983), 113. make" (facio), he puts an external appearance, a "face" (facies) on it; by this external appearance there comes a distinction so that one thing could be said to be a garment, another a dish, and likewise the various things that are made by carpenters, image makers and other workers. He who furnishes a service, whose work does not stand out in concrete form so as to come under the observation of our physical senses, is, by his action or motion (agitatus) thought rather to act (agere) than to make (facere) something. ${ }^{8}$

From the view expressed above, and other auxiliary explanations, ${ }^{9}$ it follows that facere is the resulting creative ${ }^{10}$ work that "stands out in concrete form" and "comes under the observation of our physical senses." It is not surprising, then, that to face a building means both to stand in front of it "exchanging glances" and to "finish" it, to put a face on it. What is astonishing is that these meanings still persist even in English. Thus our "to face" (to see and be seen, to encounter and be encountered, to define one's position according to the direction of one's face) is a second-round development from the noun (this time), which has nothing to do with the "original" facing as a perceptible conclusion of making (taken from ideation to realisation) from which façade, as facies, originated. The ethical stratum of "face to face" is somewhat veiled; it is more conspicuous in "fronting" (including frontage) than in "facing."

"Face to face" never ceases to be a primary condition, historically, socially and personally; it is an "irreducible relation" and remains the "ultimate situation." ible senses and the most expressive bodily surface, the face epitomises a person; facing defines the position of the whole body according to the face-direction, while fronting is the upright posture of the whole being in an attentive situation. he basic, elemental mind (I refuse to call it primitive), facing was a matter of equally basic ethics, that, naturally, reflected social interactions; it was reflected in the perception of social spaces and, finally, in aesthetics. Before they reached "very" advanced stages most cultures had considered that meeting full face, both friends and foes, was a measure of decency, and not only of courage. It was also a measure of giving and receiving honour, and of dignity. Appearing and meeting in person, face to face, is a privileged modus of social encounter and exchange, although not the only one. Most languages still entail idiomatic remnants of this understanding. Since "face to face" was proper, morally uplifted interaction, frontal posture became the elevated, "right" posture, and frontality a lcgitimate, in itself dignified, if not the "right" aesthetic principle. ${ }^{12}$ This axiomatic, "irreducible" and "ultimate situation" in human interrelations was a foundation for all subsequent, more abstract human institutions. One "faces" gods and demons, death, adversity or "real" life, even buildings and altars. The requirement is situational: two parties at a certain spatial distance concentrate on each other, front each other, measuring, learning and sensing each other's surface and beyond 

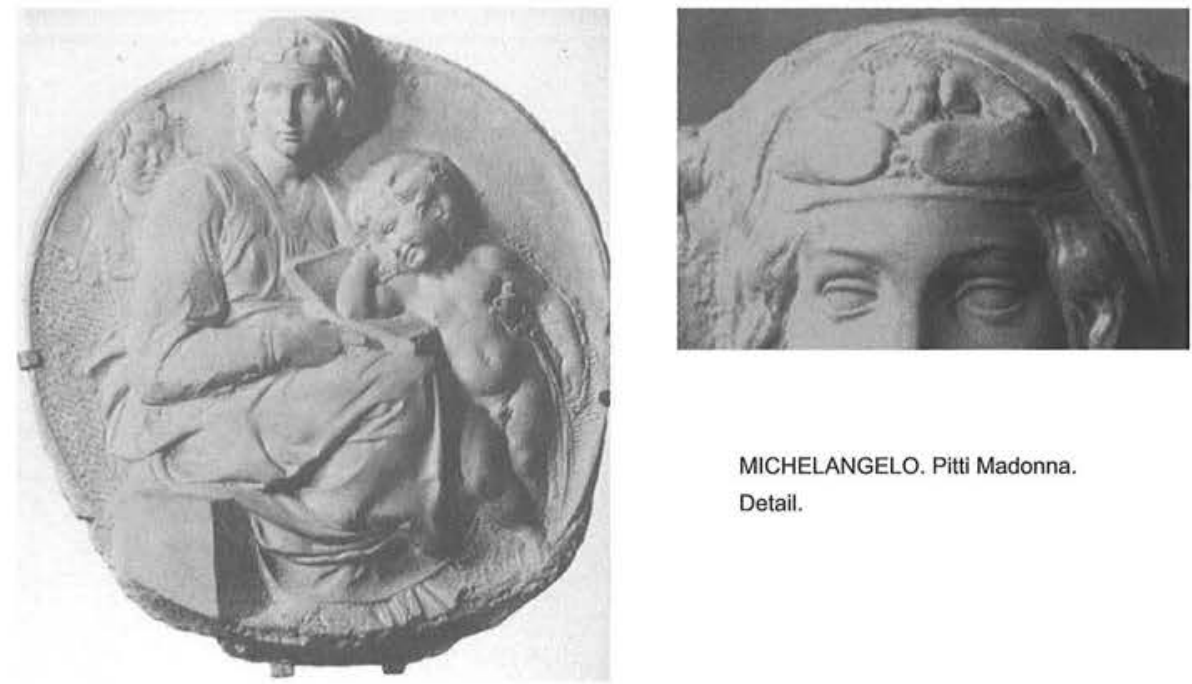

MICHELANGELO. Pitti Madonna.

Detail. the surface, usually looking at each other. Eye to eye ${ }^{13}$ is synonymous with face to face. Yet the spatial distance is filled with and modified by another distance, an ethical distance, measured by the level and kind of respect between the "facers." Superficially, facing is a frontal appearance, an exposition of the fullest and, on the human level, most vulnerable surface of oneself, but it also provides an opportunity for an exposition or exhibition of the most dignified and/or most impressive "surface" of oneself. Adoration, protection and decoration are therefore responses to and extensions of real and imaginary facing. The first of these belongs to love, which never tires of a beloved's face (adornment coming along); the distances are shortest, and the space private, intimate. The latter two "excel" in the social realm and have a lot to do with the sizing of ethical interspace. Decoration, we need to keep in mind, derives from decorum - dignity, the sense of inner moral value, and the most desirable property in the self-presenting of buildings, according to both Vitruvius and Alberti. Honour and honesty are related and revolve around distinguishing and dignifying. Alberti talks about honesta as that inner, appropriate relation of parts from which decorum, as grace and excellence, results. Ornaments may be added to enhance decorum, but not to create it. The prospect of a close encounter with the supernatural added the irrational categories of reverence and awe to the facing through the a priori infinite distances set between the revered and supplicants. Temples, of course, were meant to be faced frontally, to be approached directly, and so were the statues they protected. The fronton, ${ }^{14}$ though, remained a protruded forehead - a pediment, gable. In my view, the astonishing forehead of Michelangelo's Pitti Madonna presents an eloquently delicate intertwining and overlapping of the ideas of the face, front, fronton and façade unfolding here. The result is a temple-face with an arched pediment created on (out of) the Madonna's forehead. Framed within a gentle curvature of her scarf and her lower headband is a winged head that rests on a heavier, "velvety" headband or diadem (fascia, tenia) interrupted at the centre with what seems a precious stone. The insufficiently developed facial features of this fronton guardian veil his/her age and gender. To me, he looks like an older male rather than a child. This is an invaluable example of face made façade.

Alberti diversified the vocabulary of the building's face by applying both frons and facies to the façade; and vultus and facies to human, animal and the faces of statues. ${ }^{15}$

As a verbal noun, facies pertains to the inanimate more than the animate. It implies an outcome, a product, a result of a manual effort visible on its object, and consequently carries along an air of artificiality and pretence. Literally, it meant an outward appearance, aspect or expression (susceptible to change, se in omnes facies vertere: literally, to change in every way
13. In English, however, it is taken to mean accordance between the parties and not a discourse which would include tension arising from their differences. This also means the most open in a discrete exchange.

14. Maybe from fronto, frontonis f., a person with a big forehead.

15. De re aedificatoria, $7.16 ; 8.1$; and Momo o del principe (240) on Stupore, to mention just a few (loca) occasions. 


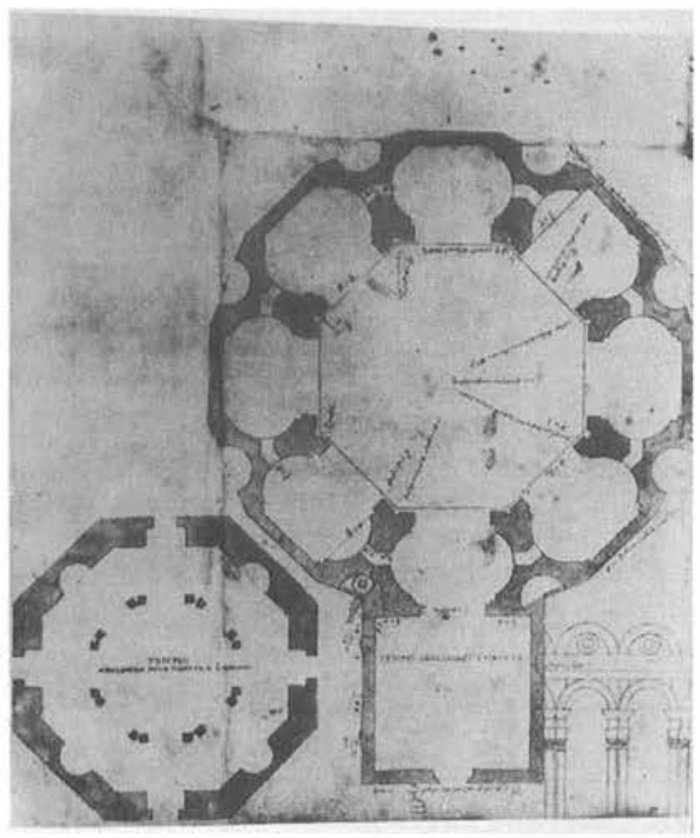

16. Which is clearly a later development, although in common use in literature during Augustan times (for example, Cicero, Horace, Virgilius and Ovid).

17. The modern Italian il volto (face) is a descendent of vultus.

18. The former indicated the ephemeral in a face, that is, an expression of a mood or character, and the latter, which is the original word for the mouth, was applied to the whole face. Os was not normally used for the face of a building but for ports and entrances of Roman houses. In the works of scenic writers, the plural denoted ornaments for the head and face; which we learn from Varro, again, as he tried-not without good, "oratorial" (oration comes from os) reason-to derive ornament from oris, although it actually came from ornare (to adorn), which is related to order, ordo, ordinis. (vi.viii.76)

19. In Italian translation: "e con gran meravglia si videro di fronte un enorme arco di triomfo di tutti i colori." Alberti, Momo o del principe, Nanni Balestrini presentation (Genova: Costa \& Nolan, 1986), 154-55

20. San Lorenzo still searches for its front. Although some of us might find its gallery of proposed physiognomies and temporary installations an interesting "body" of evidence of the impotence of "facing" the exterior of this church, this condition turns its interior into its only front. When the door is closed the square is faceless.

21. While fabbrica is a volume, faccia is a surface.

[Virgil]). It also denoted a face, countenance, ${ }^{16}$ and in transferred meaning, a character. Synonyms such as vultus ${ }^{17}$ and os, oris pertained more often to humanoids (humans and gods) and statues. ${ }^{18}$ Of the nouns and expressions derived from spectare, conspectus was the closest to "frontal appearance." Alberti utilised it, for example, in the Momus, describing a wonderfully crafted and ornate celestial triumphal arch that showed conspecto e regione maximo-literally, "with the biggest side in full view."19

The "modern" facciata was born with the Renaissance re-facing of old church fronts. Alberti was responsible for at least two. Facing the Santa Maria Novella was clearly an act of crafting, putting together a design, making of a dignified front in communication with the piazza and people in front, while standing in front of and representing the church behind. The unrealised facciata of the Medici church of San Lorenzo is a paradigm of the façade's separation from the building and the wall/surface behind despite a huge portfolio of designs. ${ }^{20}$ The wall and the face/façade are different. The face engages in dialogues (even choruses); the wall is voiceless and faceless. Except for being a division it does not communicate anything but displays materials and their finishings, often seen as faces. With or without holes the wall is lifeless, unless some breathtaking legend engages the imagination to persuade us otherwise. But it is the face given to the wall, made on or with the wall (and the floor or ceiling too), that is delegated to communicate with people and given conditions, to participate in their "situation." The relative autonomy of the appearance of Renaissance buildings contributed to an understanding of the artificiality, replaceability and shallowness of the façade. Faccia was necessary to close, cover and protect spatial incongruities; it was still a face, an intrinsic part of fabrica $^{21}$ as the whole opus, and its removal would produce a transverse "section" of the building. Facciata bordered being a possible object per se, a veneer or tableau, an articulated, dispensable surface, a skin over the wall, later to be commonly seen as a mask in its "modern" sense of non-identity, rather than the desired, borrowed or attracted identity the mask used to mean to "less sophisticated" societies. ${ }^{22}$ This realisation, together with the restructuring of other social spaces in the Renaissance, produced a serious rearrangement in the ethico-aesthetic sphere. Due honour and dignity became proportional to the mixture of the newly formulated value categories of magnificence and meraviglie. $^{23}$ 
An insight into a more general and casual understanding of "façade" comes from an ordinary statement made in 1485 by an ordinary, yet informed, Florentine commentator on an extraordinary work. Describing Brunelleschi's oratory, Santa Maria degli Angeli, the first centrally planned monument built in the Renaissance, Manetti wrote, "This temple was built with sixteen outside faces, eight inside faces and also with eight faces above the chapels." 24 The temple, of course, was to revere God and honour the Commune. ${ }^{25}$ This mundane description, written half a century after the initiation of the oratory, a period filled with an incomparable bustle of construction in and around the city, provides clues about status of faccie. Appearances, sides, views, surfaces, faces or facings? We learn that for Manetti every intersection of three planes constituted a new faccia, which enabled him to count sixteen exterior "faces" on the octagonal building plan, whereas both Rustici and Vasari, in earlier and later accounts respectively, would reckon only eight. ${ }^{26}$ The faccie on the upper level above the chapels, which expressed the change in depth, were worth counting separately. Finally, faccie "existed" both inside and outside ${ }^{27}$ which underlined the continuity, if not the permeability, of a building's "in" and "out," a trait that was "original" to the Italian Renaissance, considering its reliance on the solid wall. It was this kind of building, so dear to Renaissance architects, that contributed modern ambiguity to the simplicity of the monodirectional "face to face." It also paved the way for the poly-frontal edifices we now take for granted. It should be mentioned here that the entrance often was, and still is, the only building part that truly allowed "face to face" relations on a human scale; the entrance is equally primary and "irreducible" as a "face to face" situation itself. With the main façade problematised by the poly-frontal treatment of centrally planned edifices, it was the main entrance (ianua principalis) that determined the principal face/façade; a hierarchy of accesses (main road, piazza, "front garden-park") reinforced it on the social level.

The matter is complicated. Ethics and aesthetics both deal with value judgments and emotions; "correctness" and a sense of beauty are more intertwined than commonly thought. With our present understanding of the mechanisms of perception and attention, and their effect on the dimensions and appearances of buildings and urban situations, architects have lately reasonably concentrated on the fragmentary, obtuse (angled) and oblique, and the "cadre." Neither much space nor much willingness seems to be left for a "face to face" encounter with buildings. A less involving, less obliging and less defined, "in passing" mode with ever smoother façades corresponds to the increase of the shallow and peripheral in interhuman relations and to a general "speeding." We can only hope that, this time, the present taste for slanting and curving is neither an echo of, nor will be echoed by, ethical slanting.

Semantics is the easier part. Could we benefit from a comprehension of the inadequacy of our indelicate use of the term "façade"? We use it to encompass a number of meanings: from the actual view and position of any building surface, including the front, for which the word "aspect" is better suited; to the vertical representations of projects in "paper architecture," views brought up from plans, for which the only correct term is "elevations," as they are a demonstrative architectural tool "elevated" from drawings into an impossible view, an apparition, recognised in the old term orthographia. The façade as a cover-up is a choice and not a rule. We might need to brood a little more on the free façade.
22. Although intending to stay within my anthropological limits, I should not refuse the benefit of invoking (briefly) an unrelated culture and its related image, like the intricately carved (abundance of facere) Polynesian parata or koruru face/head, a model for a facial design actually incised in vivo. Lack of space, unfortunately, prevents elaboration.

23. It does not seem viable to me that the Renaissance obsession with central perspective had much to do with ethical considerations.

24. "El quale tempio e fondato di fuori a faccie sedici, ed a faccie otto nel drento, e dalle cappelle in su, faccie otto medesimamente." Antonio di Tuccio Manetti, "Vita di Filippo di ser Brunellesco," in Divo Savelli, La rotonda del Brunelleschi: storia e documenti (Firenze: Esuvia edizioni, 1992), 45.

25. "Ad Dei reverentiam et Communis honorem ..." In Atto notabile per la construzione della rotonda degli angeli (16 aprile 1434). Manetti, 41.

26 . And literally everybody else up to the twentieth century-myself includedwould see, or repeat, sixteen. The consensus was that the building was extraordinary, bizarissimo, in Vasari's words.

27. If this building, as it is believed, was intended to have pronounced structure and austere ornamentation both inside and out, it is appropriate to present it as double-faced, with an almost interchangeable inside and out that might be comparable to reversible (doublefaced) garments. Exemplifying the effect of the back wall of Arena Chapel David Leatherbarrow raised another interesting issue - an "inside front." 